\title{
PERFORMING ROYALTY IN CONTEMPORARY
} AFRICA

\author{
SUSAN COOK \\ Harvard University \\ REBECCA HARDIN \\ University of Michigan
}

Sovereignty and governance in contemporary Africa are hotly contested issues with important - even dire-consequences for all those interested in the continent's markets, resources, people, and welfare. This article focuses not on questions of how authority is assigned or removed, but on how it is shaped, worn, and performed for diverse audiences, particularly in the arena of "traditional governance.” To do so, we juxtapose two ritual celebrations, in two distinct monarchies in southern Africa, to show contemporary traditional leaders engaged in cultural displays in their own contexts, and in contrast with each other's. First, we describe the formal enthronement of Kgosi (or King, as most Bafokeng translate it) Leruo Molotlegi of the Bafokeng Nation in South Africa in August 2003. We then follow Kgosi Leruo one year later, literally and ethnographically, on an official visit to King Mswati III of Swaziland for the traditional Reed Dance ceremony (umhlanga). Here, the Bafokeng "ethnic corporation" meets Africa's last absolute monarchy in a juxtaposition of styles, symbols, and strategies that illuminates the difference between an aesthetic of defiant African alterity and an Afromodern capitalist cosmopolitanism.

In chronicling the meeting of these two men, whose roles as royals have developed under very different political and economic circumstances, we examine their disparate choices for self-presentation and political ceremony in order to show 
the dichotomy between "tradition" and "modernity" as a tangible resource for those pursuing a "middle way" between customary chieftaincy and the most deleterious effects of late capitalism in Africa.

We thus sketch, primarily through the eyes of Bafokeng leadership, an emic understanding of "culture," both implicit and explicit, within the realm of "governance," and with respect to poles of tradition and modernity. A second dichotomy, that of "African" and "Western" also serves as a binary that leaders alternately rely on and reject, both rhetorically and institutionally.

To explain these seeming contradictions, we refer to recent considerations of "theory from the south," the proposition that "it is the global south that affords privileged insight into the workings of the world at large" (Jean Comaroff and John Comaroff 2012b:1). We ponder whether and how the hybrid form of ethnically based governance and resource management being pursued by the Bafokeng is a harbinger of nondemocratic redistributive and consultative political strategies elsewhere. We consider this question not only in light of the Bafokeng Nation's relationship with systems in European, Asian, or American settings, but also in relation to alternative practices within other traditionally governed African societies. These latter, we note, are crucial audiences, rivals, peers, and inspirations that shape Bafokeng financial, ecological, and cultural practice.

This analytical attention to various distinct "souths" is not to reject a vision of the Bafokeng as emblems of particular late capitalist formations and modes of global citizenship. It is instead to remember that "theory from the south" emerges from localized social practices as well as material exchanges across and between African nations (and nations within nations). True, Africa is "rising" and "theorizing" on world economic and intellectual stages. But these things occur through both collective rituals and individual agency among a wide range of African actors, each with their respective senses of African pasts, and of how those pasts shape present identities and contests.

In the cases presented here, African traditional leaders look to the geographic, economic, and discursive West for capital, credibility, and consumption of goods and services, while at the same time traveling the entire globe for pleasure, trade, and developmental models. Elements of such diverse global references work their way variously into these leaders' personal and public repertoires (see Supporting Information Figure S1). But these leaders also circulate widely within Africa, in ways that are especially crucial for adjusting their own assumptions and priorities. In doing so, they both reproduce and redefine historically rooted ritual practices that mark seasonal transitions and ascension to leadership with expressive elements like 
bare-breasted dancing, virginity rites, and the display of sacred and symbolically charged items such as spears, shields, and animal skins (see Supporting Information Figure S2).

Such details appeal to a wide variety of inhabitants of, as well as visitors to, these African worlds. For other constituents, however, these rituals conflict with discourses of rights, accountability, modernity, and competitiveness, perceptions that matter and must be made sense of in struggles to ensure sustainable modes of reproduction for the modern "tribe." Wary of our work being relegated to the study of "peripheries" within world systems, we seek to avoid triumphalism about such sites morphing into new cores of late capitalism. Instead, we document doubts within and debates among those groups we study, attending to their specific terms of discussion about community, legitimacy, communication, and cultural sovereignty. ${ }^{1}$ Thus can anthropologists move beyond reflexive cultural critique into analysis of new and nuanced deployments of "culture."

\section{SEMIOTICS AND SOCIAL ANALYSIS OF AFRICAN ROYALTY}

To better understand how "traditional governance" in Africa relates to the most recent forms of neoliberal- and capitalist-world ordering and re-ordering, anthropology must take into account the widest possible range of contemporary realities for those who place themselves in the category of "traditional leaders." We are interested in the distinct positions they stake out with respect to ritual performance, economic development, governance mechanisms, and cultural identity. By looking at the Bafokeng Nation as one case of African traditional leadership, and observing its articulations with another African kingdom, we throw into relief both recent and historically rooted formulations of "traditional culture" that are central to emerging tribal institutions. ${ }^{2}$

Following Hobsbawm and Ranger (1992), we take "traditional governance" as a broad label for forms of local political organization in Africa and elsewhere in the postcolonial world. These have some relation to precolonial political structures, while recognizing that those relations were contested, claimed, even "invented" as tradition under the complex circumstances of colonial rule. A growing body of work in anthropology and other disciplines has reflected on the political [il]legitimacy of contemporary chieftaincies and kingdoms in Africa, especially with reference to democracy and democratization (Mamdani 1996; Ribot 1996; Ntsebeza 2005; Oomen 2005). Others posit a milder view of the durability, flexibility, and innovation of traditional governance systems (Rathbone 2000; Wastell 2007; Skalnik 
2004). The ethnography presented here seeks to offer detail and complexity to a set of debates too often tending toward generalizations.

For the employees of the Bafokeng tribal administration, who work in sleek corporate offices, contemporary traditional governance idioms are forged precisely in the face of primitivist critiques of African political legacies. Their blending of traditional and corporate practices enables a bid for membership by their governing elite in global communities of capitalist asset ownership, while simultaneously enabling them to reproduce a collective history of exclusion from formal political power under colonial and apartheid regimes. Let us consider some of the historical and cultural contexts for such practices.

The Bafokeng are Setswana speakers based in South Africa's North West Province, about one hundred kilometers west of Pretoria. They are one of about fifty Tswana chieftaincies in Botswana and South Africa that have been intensively studied by colonial historians and anthropologists (Schapera 1943, 1952; Schapera and Comaroff 1991; Breutz 1953; Coertze 1988; Jean Comaroff and John Comaroff 1991; John Comaroff and Jean Comaroff 1997; Legassick 1969). Scholars have been interested in the Sotho-Tswana cluster for the ways in which their cattle-based economy shaped polities that curtailed the development of internal secondary sources of political power, that is, paramount chieftaincies (Gulbrandsen 1995), and effectively resisted and shaped colonial forms of administrative authority (Wylie 1990; Landau 1995).

The Bafokeng currently own and occupy 1,400 square kilometers of land located within the Bushveld Igneous Complex, the richest known reserve of platinumgroup metals in the world. The 150,000 people who live in the 29 villages that make up the so-called Bafokeng Nation are about 65\% ethnic Bafokeng, and 35\% people who have migrated into the area in search of work in the platinum mines (RBA 2011).

Like the many other traditionally governed communities in South Africa today, the Bafokeng community has been crucially shaped by the politics of empire and the economic transformations that began in the early 19th century. Later, apartheid policies impacted the Bafokeng system of leadership as they did in other rural parts of South Africa. The Bafokeng kgosi during the apartheid era, Lebone I, resisted incorporation into Bophuthatswana, the Tswana "Bantustan," then declared his intention to secede from the homeland in 1983. He was eventually accused of sponsoring a coup attempt and was forced into exile in 1988 for the remainder of the apartheid period. His brother George Molotlegi ruled in his place, and proved more cooperative with the homeland authorities (Manson in press). 
The South African constitution recognizes the existence and authority of traditional communities in South Africa, but does not give them sovereignty within their territories. The state maintains administrative control over areas that pay allegiance to a traditional leader, as well as those that do not. After the 1994 elections, Kgosi Lebone I reclaimed his position as leader of the Bafokeng community but died soon thereafter. After his death in 1995, his eldest son, Mollwane, took the throne. When he died in 2000, his younger brother Leruo ascended to the position.

The Bafokeng governance system has its roots in classic Tswana political structures but also features newly elaborated institutions and roles. The kgosi presides over a council of headmen (dikgosana) who are chosen through rules of male primogeniture. Each headman governs within a ward (kgotla), of which there are currently 72. In addition, there are also elected and appointed councilors who sit with the headmen in the Bafokeng Supreme Council, or traditional legislature, and preside over the Bafokeng Tribal Court, which rules on cases according to a semi-codified set of customary laws. These structures, together with the community-wide meeting known as kgotha-kgothe, are the principal vehicles of governance in the Bafokeng Nation. The Bafokeng administration operates like a small municipality, overseeing infrastructure and services such as water, electricity, and waste management. Other community institutions include Royal Bafokeng Sports, which manages the Nation's sporting investments (a World Cup stadium, a high-performance sports complex, and a professional soccer team), and the Royal Bafokeng Institute, established to upgrade the quality of education in the nation's schools.

These institutions are increasingly intertwined with the intricate investment structure of the nation, which seeks economic and geographic diversification, even as it tries to maximize its interests in, and return from, platinum mining (Cook 2011). Royal Bafokeng Holdings, located in Johannesburg, has acquired shares in a wide range of companies, in a diversified portfolio with an estimated net asset value of R35 billion (approximately USD 4 billion) at the time of writing. The Bafokeng executives are thus fashioning the nation into an "ethnic corporation," whose existence and identity relies on distinct political and historical realities, but which does not necessarily issue dividends to its "shareholders" in the conventional way (Cook 2005; John Comaroff and Jean Comaroff 2009).

\section{A HISTORY OF PRESENT ETHNOGRAPHIC ENGAGEMENT}

Cook met the current Bafokeng kgosi, Leruo Molotlegi, in 1997 while doing fieldwork on varieties of Setswana. When she first interviewed Molotlegi in 1997, Mollwane was the kgosi, and Leruo could hardly have imagined that he would 
become king. Mollwane had been groomed for the throne and had become kgosi at the age of 30. The chances of Leruo, second in line after his brother Fosi, ascending to the position of kgosi seemed remote, at best. Then, in April 1999, tragedy struck: Fosi was murdered in Johannesburg. In March 2000, Mollwane died of an acute illness. Leruo ascended to the position of kgosi, and shortly thereafter, invited both Cook and Hardin to Phokeng for a brief consultancy. He was seeking perspectives on his social policy agenda that he believed anthropological insight could offer.

Our brief was to conduct interviews with a wide range of leaders and constituencies within the Bafokeng Nation and summarize the principal challenges for the new kgosi. We spoke to mining executives, educators, religious leaders, health officials, hereditary leaders, activists, and ordinary community members. Our report identified and analyzed a number of major policy challenges, including unemployment, education, HIV / AIDS, and land tenure.

An interdisciplinary, cross-cutting, trans-Atlantic conversation ensued. Kgosi Leruo criticized academic anthropology for being arcane and uninterested in effecting the very changes it claims to analyze and understand. Hardin and Cook in turn drew Molotlegi out about his priorities for his people, such as the need to empower women in a community that is staunchly patriarchal. In these ways, we are contributing to an emerging body of "engaged anthropology," which considers the temporally attenuated, ethically complex, and institutionally diverse trajectories of anthropologists who straddle divides once known as "academic" and "applied" (Hardin and Clarke 2012). When we received invitations to Leruo's enthronement as Kgosi of the Bafokeng Nation in early 2003, we readily accepted.

\section{SOUTH AFRICA, 2003}

The enthronement, part traditional, political ritual and part international brand launch, took place at the Royal Bafokeng Sports Palace in Phokeng, the nation's administrative capital. The enthronement of the 35-year-old Leruo was the first installation of a Bafokeng kgosi since 1958, when Leruo's father, Kgosi Lebone I, was installed. The event was organized by Johannesburg-based "experiential marketing and communications" firm VWV. There were corporate sponsors, larger than life television monitors, red carpets, a field show, and a gala dinner. On the morning of the event, well-heeled invitees from South Africa and farther afield arrived in luxury cars and were ushered to their seats by young Bafokeng volunteers sporting T-shirts with Kgosi Leruo's image on the front. While community members sat in the open stands, the cordoned-off VIP section was reserved for 
about 2,000 invited guests, including Cook. The cool and quiet suites of the VVIP section, where Hardin sat, were stocked with spectacular floral arrangements, trays of pastries, and recent editions of mining magazines and South African press featuring the young king in his elegant suits and ties, smiling for the camera or sitting, solemn, for a portrait of "leadership."

The mood was festive and celebratory as the proceedings opened to the a cappella sounds of Shades, a gospel choir from Yale University, flown in for the event. On the royal dais, "former president Nelson Mandela sat among dignitaries that included former Botswana president Sir Ketumile Masire, South African First Lady Zanele Mbeki, and Botswana Vice-President Ian Seretse Khama” (South African 2003).

The stadium itself was thus organized into variously exclusive zones, each producing or reinforcing social networks or constituencies of the Bafokeng Nation. The South African (2003) reported that

The dazzling ceremony, which cost more than R10-million according to George Khunou, projects manager of the Royal Bafokeng Administration, saw a disappointing 15,000 crowd leave rows of empty seats in the 45,000seater stadium. Khunou said transport difficulties and tight security had made it difficult for many Bafokeng to make it into the stadium. However, some locals, who declined to be named, said there was widespread disapproval in the community of the elaborate ceremony.

Did the Bafokeng disapprove of such display? The semiotics of wealth in the Bafokeng nation represents both continuity with the past and new understandings of conspicuous consumption and economic inequality. The idea that the leader should not only possess more wealth than his followers but that he should also display and distribute it goes back to the political economies of pre-capitalist societies. Through patron-client relations and networks of subchiefs, the chief's herds and grain surplus could (and should) be distributed to prevent starvation in years of poor rainfall or disease. In Tswana societies, the kgosi received tributes in the form of elephant tusks, lion and leopard skins, and an ox from the father of every child initiated. Later, after the advent of the migrant labor system, the kgosi could claim $£ 1$ from each returning migrant worker (Mbenga and Manson 2010).

The sense that the kgosi and the royal family should ensure the survival of the people persists among the Bafokeng. The fact that the community is often called "the richest tribe in Africa" (Manson and Mbenga 2003) stands in contrast to the fact that about half of the community's households describe themselves as "poor" or 


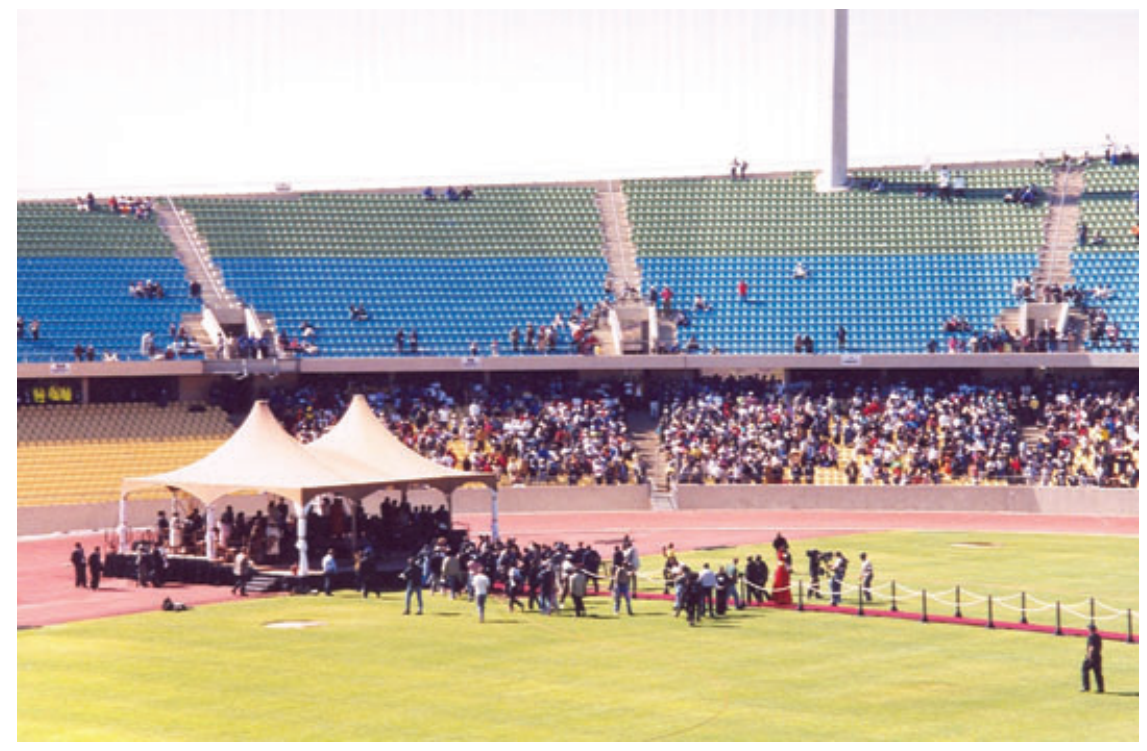

FIGURE 1. Empty seats in the Royal Bafokeng stadium during the enthronement ceremony August, 2003. (Photograph by Rebecca Hardin.)

"very poor" (RBA 2011). But rather than push for the right to claim their share of the community's wealth in cash, most Bafokeng adhere strongly to the paternalistic model by which their long-term survival and needs will be catered for by the kgosi and his administration.

Kgosi Leruo's own strategic vision is centered on a plan to invest in the community's infrastructure and institutions so that every subject in the kingdom has the opportunity for self-sufficiency and a business model aimed at achieving sustainable financial returns to the administration for the services it provides. The spending strategy is targeted at building enabling infrastructures (education, health, economic development, food security, and environmental management) that allow people to become economically active and competitive in the national skills pool. Over time, the beneficiaries of these services (who do not pay any form of property tax) will be expected to pay for them (waste collection, school lunches, water, and electricity). This "developmental" approach is similar to that of the South African state; the major difference is that the Bafokeng administration has greater capacity than the local organs of the state to implement its plans for the area.

And yet, the empty stadium seats suggest that there are important shortcomings in the strategies for outreach, communication, and incorporation of subjects into this forward-looking plan. It seemed at times during that day like there were 
more visitors than locals involved in the event. Inviting outsiders to share important occasions is not new to Tswana political culture. Supporting Information Figure S3 depicts a colonial era event where special seats were reserved for European administrators and their families. Sometimes this entailed the exclusion of local spectators, such as those pictured here outside of the enclosed ritual space, struggling to see the events inside.

Beyond the rows of elegantly clad guests at the 2003 enthronement, we could glimpse Kgosi Leruo on the royal dais, clad in a navy business suit with a leopard skin draped around his shoulders (Supporting Information Figure S4). Against the advice of his doctors who had recently repaired his Achilles tendon, he respected several elements of the ritual that required extensive standing and walking. He arrived in the stadium in a donkey cart, which, he told reporters, symbolized his status as a servant of the people. The image of the "platinum king" entering the stadium in a humble donkey cart was heavily photographed, by both national and international media.

After several hours of speeches by prominent politicians and traditional leaders, Kgosi Leruo rose to give his inaugural address. He exhorted future generations "not to abandon the ways of our forefathers, only to emulate those cultures that have, historically, denigrated our ways." Outlining a shared vision of black African identity linking Bafokeng to the rest of the continent, he said:

We denigrate traditional leaders while we fawn over European royalty. Our children are not encouraged to learn about our cultures or languages and they have no sense of pride instilled in them to be African. Do we want to bring up children who only speak European languages, who scoff at cultural practices and traditional arts? Who buy into the idea that "traditional" means backward and that anything African is inferior? I don't think we do. [Printed speech in Cook's field archive]

At the same time, he promised to "modernize" the Bafokeng Nation, using platinum revenues to invest in a diversified portfolio that would provide prosperity and opportunities for Bafokeng well into the future. That he used the term modernize almost exclusively in relation to economic strategy is telling. He never implied that patriarchal, hereditary forms of governance were up for debate. Thus, at the enthronement, as in other public moments in the life of the Bafokeng, troublesome dichotomies such as "tradition" and "modernity" are nearly unavoidably useful, even to those struggling hardest to transcend them, thereby defining new, even posturban "expectations of modernity" (see Ferguson 1999). 
At the gala dinner that evening, the speeches were more informal than those delivered at the stadium, and ritual in African idioms was at a minimum. Not a "traditional" component of a kgosi's installation, this part of the day was hosted in a huge ballroom within the nearby Sun City Hotel and Casino complex. It was less about nation building, and more about marketing the Bafokeng brand. At the same time, for the image of the contemporary ethnic corporation to work, its historical roots needed narration (John Comaroff and Jean Comaroff 2009). A documentary film projected onto four different IMAX-sized screens showed the King walking through a dark and desolate landscape as a resonant male voice narrated the challenges faced by his ancestors in the early days of colonialism. The message was one of continuity and deep history (recall the parameters of "tradition" mentioned above) and the sage leadership of the Nation by wise men equipped to see their people through wave after wave of political, social, and economic vagaries.

The film faded into a stage show by modern dancers clad in a spectrum of earth-toned leotards. They moved through clouds of mist as a narrator retold the story of how the Bafokeng arrived in their present location, this place of dew (phoka), with its excellent fodder for their cattle. The tempo of the music lifted as they depicted the hope that their land would sustain future generations, represented by a well-disciplined chorus of young singers in a triumphant shade of yellow. A tuxedo-clad Kgosi Leruo asked his mother to join him on stage so he could lead the crowd in singing "Happy Birthday" to her. The King's younger brother, Prince Bothata, spoke briefly. Kgosi Leruo, on crutches and in significant pain from his sports injury, made a few brief remarks, thanked his followers, then left the party early to retire to a hotel suite in the Sun City complex, high above the crowds of enthronement guests and Middle Eastern families on holiday.

\section{SWAZILAND 2004}

The Bafokeng enthronement ceremony was not an unmitigated success as political rituals go; the social and economic chasms among Kgosi Leruo's various constituencies and key collaborators are simply too vast. The aspects of the ritual performance that felt familiar to South African and international elites, such as the American choir and the European menu, were alien and unnecessary expenses according to many Bafokeng. The long speeches and lengthy rituals were reassuring to traditionalists in the audience but were perhaps a bit monotonous for the corporate crowd. Almost exactly a year later, we would remember the empty rows of bleacher seats at the enthronement while sitting with a delegation from the 


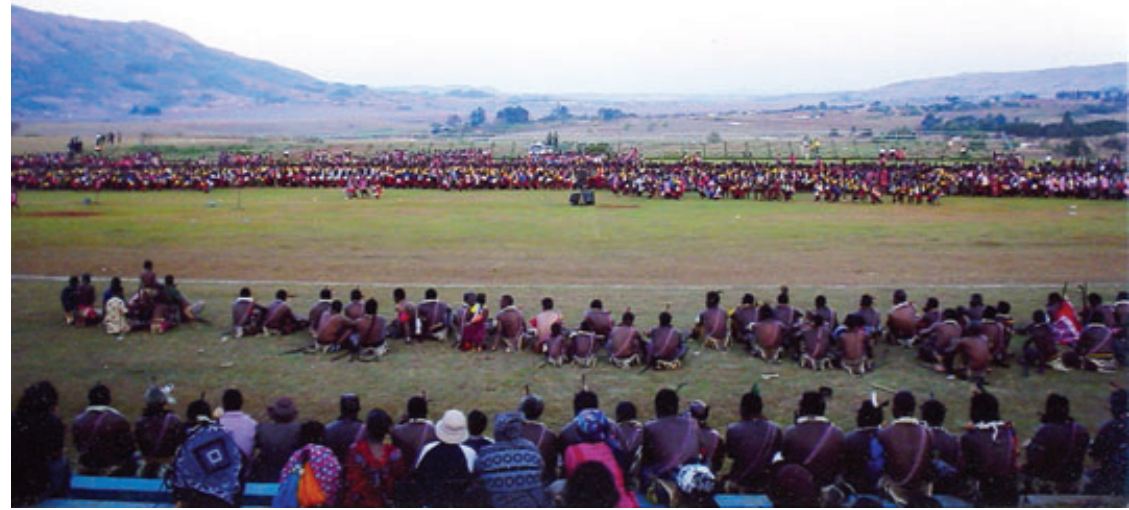

FIGURE 2. Several rows of actors in the reed dance of August 2004, in Swaziland, including spectators (seated on simple outdoor bleachers), King Mswati's retinue of male supporters (seated on the ground), and in the distance the many groups of young women in brightly colored knit tassels standing in preparation for marching and dancing.

(Photograph by Rebecca Hardin.)

Bafokeng Nation at the traditional Reed Dance ceremony at the royal compound in Swaziland.

Swaziland, Africa's last absolute monarchy, is an independent country that is nevertheless inextricably intertwined with the social, historical, economic, and political contours of South Africa. Landlocked and bordered by South Africa and Mozambique, Swaziland's economy relies on international aid, agricultural exports, and, to a smaller extent, tourism and mining. Swaziland has the highest HIV rate in the world (26\%) (UNAIDS 2009), with an average life expectancy of 32 (IRIN 2009). The population is overwhelmingly rural, poor, and subject to frequent food shortages as a result of drought. Swaziland's King Mswati III sits at the head of a government frequently classified by foreign analysts and national activists as a kleptocracy. Yet, this monarchy fascinates many foreign observers (see the recent documentary When the King Is Gone). Further, as we watched the 2005 Reed Dance ritual unfold from our place among the Bafokeng delegation, it seemed vibrant_-almost defiant.

The Reed Dance is not an ancient ceremony but has an important history in Swaziland nevertheless. Once a year, childless, unmarried women collect reeds from their villages and carry them to Ludzinzini to rethatch the Queen Mother's 
house. The ritual reflects the intertwined political powers of the Swazi queen mother (Indlovukazi) and her son, the Ingwenyama. ${ }^{3}$ Over the years, the ritual has been resoundingly criticized by the international press, which nevertheless engages in a predictable seasonal reproduction of the story for a reading public that seems to enjoy the particular, sexualized vision of black African "tradition" that provokes titillation and scorn. For instance:

The facts of the case read like a feudal fable. Amorous King Mswati III, the 34-year-old ruler of Swaziland, takes a shine to one of the bare-breasted virgins dancing for him in the reed ceremony held annually in this small southern African nation. He courts her-briefly - by cell phone, then spirits her away into royal seclusion to prepare to become his tenth bride. . . Lindiwe Dlamini, the mother of the chosen . . . wants her to finish her final year of high school and become an industrial psychologist instead. So, in a country where the king is above the law, Dlamini has launched the first-ever court challenge against Africa's last absolute monarch. . . . The Mahlangu case does more than pit human rights against customary law . . . [it] is a battle between tradition and modernity. [MacGregor 2002]

King Mswati is often accused of being out of touch with the concerns of the majority of his country's populace. Many also suggest that participation in Swaziland's Reed Dance is a matter of compulsion within a state that can effectively suffer its citizens - perhaps especially young women - to comply (BBC 2002a, 2002b). In 2005, the year after we attended the Reed Dance, the King selected a bride younger than 18 years of age, after which her mother pursued a lawsuit, and three hundred of her peers demonstrated in front of the royal residence to protest the King's disregard for the chastity-respecting measures he himself instituted (BBC 2004, 2005).

However, viewing the proceedings from the vantage point of a different "royal," a visiting dignitary and his retinue, revealed much about how the situation is more complex than such a reading, alone, allows. Some of the Bafokeng with whom we traveled seemed fascinated, and even wistful, about the broad public participation - compulsory or not — in such ritual moments. Kgosi Leruo's appearance at the Reed Dance was his first state visit to Swaziland, and the first time he had met King Mswati III. We were invited to accompany him on this ethnographic adventure, and we attended the final day of the Reed Dance (the only day of the weeklong ritual that King Mswati himself attends, out of respect for the Queen Mother). 
Senior members of Kgosi Leruo's entourage had arrived the day before and met their king at the airport. They included bodyguards and drivers, a large delegation of community leaders and representatives (mostly older men and women, and two youth leaders), and a photographer. Kgosi Leruo was also met on arrival by a Swazi delegation that included H.E. Mpumelelo J.N. Hlophe, Swazi Ambassador to the Republic of South Africa, and Mr. Ndumiso Mamba, General Manager of Tibiyo TakaNgwane, a company, established by Mswati’s father as "a Swazi Nation Organisation whose main activity is to promote development as well as undertake commercial and strategic investment and preserve traditional and cultural values and heritage."

On arrival, Kgosi Leruo was invited for a short briefing at the royal guest house, and requested that we join him there. Mssrs. Mamba and Hlophe formally welcomed Kgosi Leruo to the Swazi Kingdom and described some of the cultural and political aspects of contemporary Swazi society. Mr. Mamba seemed particularly interested in the fact that Kgosi Leruo was traveling with anthropologists and smiled benevolently at us. He noted that King Mswati's father, King Sobuza, also had an "official anthropologist" who chronicled court practices and the history of the royal family. We responded that we had read the works of Hilda Kuper (1961, 1963) with much admiration. We added, however, that we were not "official anthropologists" of the Bafokeng Nation. Rather, we explained, we were pursuing independent research regarding the Bafokeng as part of our respective university-based teaching careers. ${ }^{5}$ Some of Mr. Mamba's interest, and almost all of his benevolence, appeared to evaporate, though he remained flawlessly courteous toward us and our delegation.

Contrary to widespread press reports, the officials noted, Swazi people are not critical of their king, nor are they resentful of the privileges and luxuries he affords to his (then) ten wives (and one fiancée). On the contrary, they asserted, the Swazi people are so devoted to their culture and their king that they go to great lengths to participate in major cultural events such as Umhlanga (the Reed Dance) and Incwala (the First Fruits ceremony). Kgosi Leruo, who had been listening politely while typing text messages on his cell phone to contacts back in South Africa, nodded his comprehension of this information. Looking up at his Swazi interlocutors, who seemed to be awaiting a response from him, he asked why the Swazi monarch had not done more to address international press portrayals of the nation as callous, sexist, and backward. Ambassador Hlophe responded that the Swazi character is not proud or boastful, and if outsiders choose to misrepresent the reality in their 
country, they don't feel compelled to correct them. "Let people think what they want," he said, "we know who we are."

After this formal welcome, Kgosi Leruo was taken to Ludzinzini to be received by the Swazi queen mother. Brief formal greetings were exchanged inside the compound as thousands of young women streamed by outside, depositing their gathered reeds at the residence and then continuing in a procession onto the playing fields behind the compound. Shortly thereafter, Kgosi Leruo entered the ceremonial grounds of the Reed Dance with King Mswati and his cohort of brothers, cousins, and advisers. The thousands of girls became boisterous at the entrance of their king. Mswati was dressed (like most of his male cohort that day) in animal skins and swatches of cloth imprinted with royal symbols (see Supporting Information Figure S2). He seemed content to be in the midst of the annual celebration; at his side, Kgosi Leruo seemed out of place in his business suit (see Supporting Information Figure S1).

The faces of some members of the Bafokeng delegation were incredulous at the sight of so many Swazis in rhythmic movement. They could hardly believe the outpouring of energy from the 40,000 men, women, and children who had come from all over Swaziland to sing, dance, and offer reeds for the Queen Mother's concession. The senior uncle to Kgosi Leruo, Magosi Tumagole, watched the Reed Dance with particular fascination. "This is the Master Plan!" he exclaimed, excited at the prospect of concocting a similar event in the Bafokeng context. The head of the Bafokeng Women's Group also watched admiringly as the girls made their way from the Queen Mother's kraal, at last unburdened of the reeds they had brought to Ludzinzini from all over the country. She openly expressed envy at the level of cultural participation exhibited by these young people, noting that it was not a realistic hope back in Phokeng.

The two youth leaders from the Bafokeng administration, one female, one male, asked their Swazi hosts all about the Reed Dance, other events in the Swazi cultural calendar, and how these things fit into Swazi life, Swazi identity, and the Swazi economy. To us, after reflecting on all they had learned, they said, "Ok, we are more civilized and have adopted more Western ideas [than the Swazis]. But we have our historical background . . . we have dikutle, makgotla, kgothakgothe, and we should attend to these things. We don't want to see 'Swaziland' in our backyard, but we would like to see our culture promoted more than it is" (Hardin field notes).

But would they, really? The examples identified by these two young leaders are all governance mechanisms, means by which boundaries and jurisdictions are 


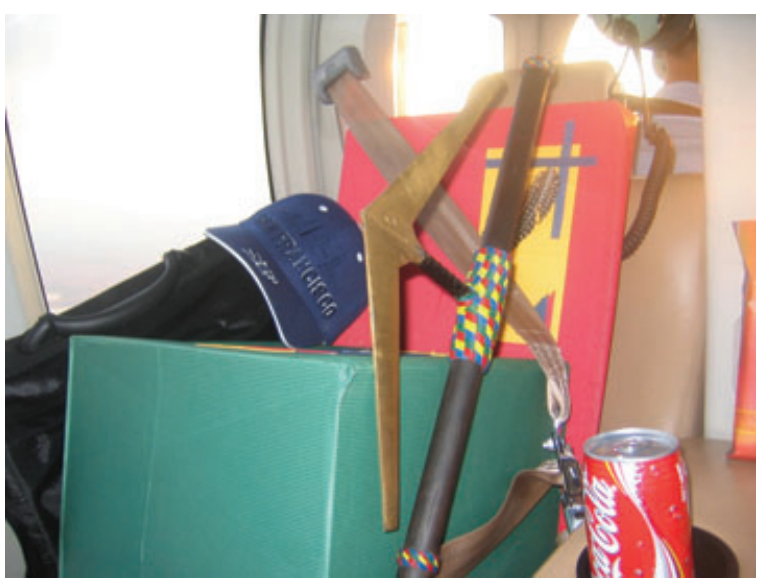

FIGURE 3. The ceremonial spear offered to Kgosi Leruo by King Mswati, sitting in the seat of the former's helicopter between a Coke and a baseball cap, on the flight back to South Africa. (Photograph by Rebecca Hardin.)

maintained within the Bafokeng community. They bear little resemblance to the rites and rituals celebrated in Swaziland, where public displays of fertility and ritual reproduction of the roles of women, youth, and royalty take center stage in widely anticipated festivals.

The contrast between the styles of the two kings on this occasion was not merely circumstantial but reflected clear choices each has made about which rituals, symbols, and styles to retain from African cultural repertoires and which exogenous styles and symbols to embrace; they index a different set of concerns and constituencies. King Mswati, wearing a cloth sarong wrapped around his waist, bare-chested, plastic feathers in his hair, and necklaces made of animal skins around his neck, held a golden-headed ceremonial spear in one hand. Kgosi Leruo, in his navy suit, light blue silk tie, and black Italian leather oxfords, held his cell phone in one hand.

When it came time for Mswati and his cohort to dance through the throngs of young women, the Swazi king invited the Bafokeng king to join him. He offered Kgosi Leruo a golden-tipped ceremonial spear of his own to carry during the dance (see Figure 3), but Kgosi Leruo politely declined, preferring to watch from the sidelines. King Mswati moved through the crowd of girls, flanked by his favorite male relatives, friends, and political allies, appraising the dancers' beauty and style. Would he choose one to be his next bride? It was in search of this answer that those around us craned their necks and speculated in good-natured conversation. 
We had seated ourselves in the bleachers, outside the section cordoned off for King Mswati and his honorary guests. There was nothing here that remotely resembled the sort of security officer-enforced protocols that had separated commoners from VIPs, and VIPs from VVIPs at Kgosi Leruo's enthronement in Phokeng. We found ourselves able to observe and converse with all sorts of spectators, from the parents of dancers, to members of the royal family, to the trickle of international tourists who had come to capture the event on camera.

For most of the afternoon we were seated next to Percy Mngomezulu, the father of King Mswati's first wife, Queen LaMbikiza (born Sibonelo Mngomezulu). She, like her father, had become an attorney and gone on to draw attention as an advocate of women's rights within Swaziland. Her father had previously served as the country's ambassador to the United Kingdom and seemed inured to - even wryly amused by_-British popular disapproval of this particular Swazi ritual.

He spoke of a "sense of belonging" to these political forms and practices, despite their clear drawbacks and challenges. He also, however, expressed concerns about current governance practices in Swaziland. Perhaps his concerns betrayed a family interest not in radical change but in their own access to the mechanisms of power. ${ }^{6}$ In any case, the crowd seemed to bolster the sense of broad if measured support he was describing.

King Mswati did choose a fiancée that day - a relief to supporters of the royal family. Some in the crowd suggested to us that at his age (36), to have fewer than 20 brides reveals a kind of negligence of the role that the king's marriages play in creating kinship-based connections across the regions of Swaziland. In order for the concerns of constituents to be effectively conveyed, and for resources to be effectively distributed among the various areas and identity groups of the nation, it seemed more wives are needed. They should be chosen less according to their beauty or youth and more according to their provenance and political affiliations. His choice that day of a grade nine student and former Miss Teen Swaziland finalist seemed questionable in light of these criteria.

The day after the Reed Dance at Ludzinzini, we were invited on a sort of "We are modern, too" tour that took us to a sawmill, a luxury hotel and casino, and a large dam still under construction. Throughout the day, we were struck by the contrasts in sartorial choices between the Bafokeng representatives and their Swazi counterparts (see Figure 4). Kgosi Leruo and individual members of his delegation had for the most part chosen personal styles that proclaimed their membership in a wider and more conventionally corporate world of suit jackets, neckties, or 


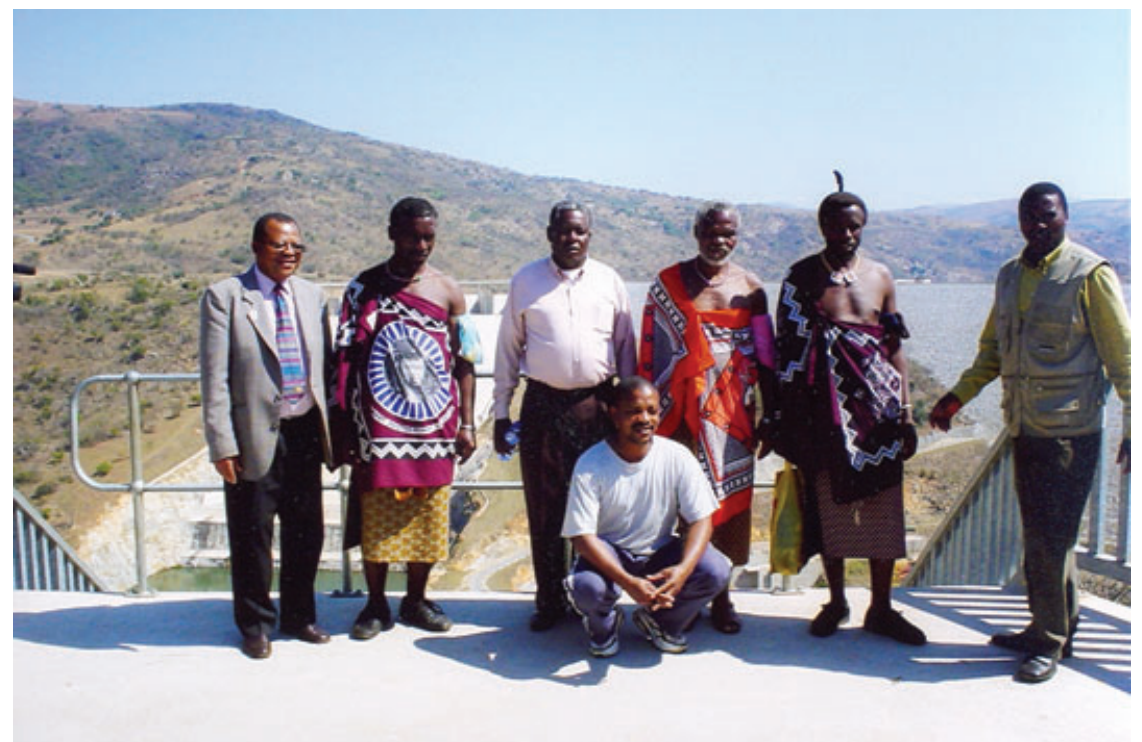

FIGURE 4. Members of the Bafokeng delegation (in shirts, including Magosi Tumagole, Kgosi Leruo's adviser on traditional affairs, far left) with their Swazi guides (in swatches of cloth) atop the Maguga Dam, which opened in 2002. (Photograph by Susan Cook.)

studied casual looks including jeans and dress shirts. We reflected on the fact that this had also been true during Kgosi Leruo's enthronement ceremony in Phokeng. Their Swazi interlocutors, on the other hand, appeared to be delightedly doing just the opposite. At least during this particular celebration, their dress included nationalist cloth prints, animal skins, feathers and ropes of beads, proclaiming their separateness from the aesthetic icons of conventionally understood global modernity (Hansen 2004; Hendrickson 1996).

This willingness on the part of Swazi elites to be-if perhaps only partially, or momentarily — proudly apart from dominant forms of the "modern" world is what many of the Bafokeng delegates seemed to find most intriguing about their Swazi hosts. This separation is also, however, increasingly becoming a liability for Swaziland as the colonial ethnography and mainstream international press accounts are joined by more careful analysis of the inconsistencies and social costs of that monarchy's lack of leadership on basic political economic and epidemiological issues confronting its constituents (Wastell 2006). The Bafokeng delegates we traveled with seemed mostly unconcerned (or unaware) of Swaziland's political troubles. Instead, they focused on the distinct possibilities for positioning a nation around issues of "modernity" and "tradition." 
On one hand they expressed a desire for more "culture" in Bafokeng life. On the other hand they seemed somewhat derisive toward the Swazi display of theirs. Throughout the visit they actively - through gestures, expressions, and explicit statements - policed the boundaries of their own sophisticated protocol. They commented that it was shameful for Swazi women to parade around bare breasted, ritual or no. At another moment, some of them requested steak knives during a meal at the royal guest house, noting that the meat they were eating was tough. When they were told that steak knives were not available, the Bafokeng delegates raised eyebrows at one another, noting this as a sign of the Swazis' lack of "civilization."

In such subtle actions and reactions, the production of "modernity" fosters the re-emergence of the "traditional" for both Swazi and Bafokeng subjects. But we must also acknowledge that most of those with whom we spoke were less concerned with such social constructions in and of themselves, and more concerned with the implications for political legitimacy and participation. Many Bafokeng felt that the Reed Dance was a haunting reminder of the challenges to contemporary Bafokeng political culture. Whatever the reasons for the empty seats at the Bafokeng enthronement one year earlier, they raised an open question for faithful Bafokeng subjects regarding the extent and expression of popular support for the office and administration of Kgosi Leruo. That this question arose around the various options for "bread and circuses" rather than around the question of equitable distribution of Bafokeng wealth is striking. Likely, were we able to talk to a cross section of ordinary Bafokeng, they would express a different set of priorities from the members of the Swaziland delegation.

What did Kgosi Leruo himself think about the ritual displays at the Reed Dance? During the event, he maintained a somewhat distant and disapproving mien, while other visiting dignitaries participated in the ritual event unabashedly. Kgosi Leruo hasn't returned to Swaziland since 2004, nor initiated any formal relationship with King Mswati's kingdom, in contrast to multiple public appearances with Ghanaian, Native American, and Maori royals. However, delegations of Swazi officials have been invited to subsequent Bafokeng cultural events, and Kgosi Leruo's mother, Queen Mother Semane Molotlegi, accepted an invitation from the Swazi queen mother to attend the Morula Festival in 2005. Given the stark contrasts between the Kingdom of Swaziland and the Royal Bafokeng Nation, specifically the different visions for economic growth and sustainability, it seems clear that future relations will remain at the level of sporadic and highly ritualized reciprocities. 


\section{FROM CORPORATE DESCENT GROUPS TO CORPORATE GOVERNANCE ${ }^{7}$}

The Bafokeng who traveled to Swaziland come from a setting in contemporary South Africa where their community identity has become an example of "Ethnicity, Inc." (John Comaroff and Jean Comaroff 2009), a primordial "brand” which is nevertheless strongly associated with the profoundly modernizing element of mining wealth and global trade. Their longing for a more "authentic" African aesthetic and affective attachment to ritual in the face of Swaziland's preservation of collective ritual performance is poignant but may be predicated on a set of subject positions shot through with patronizing and reductive attitudes about the very nature of "African culture." The question becomes the following: is alienation from "tradition" not, itself, a marker of some form of status in contemporary Africa?

Bafokeng executives are not unaware of these shifts and paradoxes, and, in fact, actively wrestle with some of the internal conflicts over who they are, where they locate power and authority, and what image they wish to project to the world. A firm of corporate branders was hired in 2006 to advise the King's administration on these issues. It didn't take long for this group of young, white, urban professionals to zero in on the fact that not all Bafokeng people approve of the image of their king as a CEO, redefining them as shareholders, and running the community like a company. At the time of this writing, the "Marikana massacre" in South Africa, and subsequent national crisis over living conditions in the "platinum belt" shone a spotlight on the sociodemographics of the Bafokeng nation and the surrounding region and the urgent need for a reassessment of the current model (Reuters 2012). As a director of Royal Bafokeng Holdings (the largest single shareholder in Impala Platinum), as well as leader of the community where both foreign workers and local unemployed live, Kgosi Leruo's position and role in such disputes is not straightforward. ${ }^{8}$ Dissension and discontent within the Bafokeng community is common and takes different forms, including contestation over land rights, disputes about equitable distribution of mining dividends, and opportunities for work subcontracted by the Bafokeng administration. Only occasionally do community members question the institution of the chieftaincy itself (Reuters 2012; Platinum Weekly 2012).

\section{CONCLUSION}

In the two cases presented here, decisions about image and interaction are not the sole prerogative of the African monarchs themselves, but are shaped by the views and responses of their constituents, weighted according to their influence over the direction of the enterprise. Local constituencies (community 
members, neighboring chiefdoms, migrant laborers, local media) receive a tacit level of attention and engagement, mostly through the perpetuation of "traditional" events and forums, the notes and minutes from which rarely reach the desks of decision makers in the corporate sphere. Less visible constituencies (mine management, investment partners, banks, representatives of foreign governments, business media, and multilateral organizations like the United Nations, World Bank, and World Economic Forum) are engaged regularly and with explicit attention to the alignment of strategy for mutual benefit.

The seats in the stadium during Kgosi Leruo's enthronement seem less "empty" if one imagines that ritual space, which creates and re-creates the Bafokeng chieftaincy, as occupied by the interests and agendas of the entire range of constituencies named above. Whether or not the VVIP suites were filled with the right dignitaries, celebrities, and business associates, and whether or not the community thronged to the occasion is beside the point. As long as the requisite rituals take place to embed the "traditional" in the "governance," the business of the Bafokeng Nation can proceed apace, unburdened by public relations liabilities such as repressive patriarchy, revered virginity, and politicized polygyny — liabilities for which Swaziland's leadership is often faulted. Such oft-decried yet publicly performed social facts, though they extend and bolster some sense of unique and authentic African identity might, after all (and especially in this era of expanding universals concerning human rights) also stand in the way of the next smooth negotiation over actual monetary ones (Mail and Guardian 2011a). Said differently, the most powerful accessories for a traditional leader in the global age might be share agreements and economic empowerment deals rather than the more symbolic trappings of strength, virility, and patrilineage that have, historically, shaped the corporate descent form across cultural contexts and territories. And yet these latter things still do matter and are at the heart of alliances across traditionally governed political entities, as well as between a given leader and his or her shifting constituencies.

It thus behooves us to take seriously the ways that actors within "traditional" systems themselves consider the relationship between their past and their possible future, and also their roles in forging hybrid forms of political governance and wealth management. Examining how African royalty opens out new terrain on which traditional governance mechanisms articulate with democratic ones, but also with capitalist ones, resonates strongly with the argument that it is in the global South that "radically new assemblages of capital and labor are taking shape, thus to prefigure the future of the global north" (Jean Comaroff and John Co- 
maroff 2012a:12). Clearly demonstrating that culture and identity are important elements of that equation, leaders such as Kgosi Leruo Molotlegi of the Bafokeng are positioned not on the sidelines but rather at the forefront of tensions between the representative political processes that characterize contemporary state politics and emerging cultures of corporate governance, indeed corporatized life (Welker et al. 2011). These tensions, refracted through the expansion of transnational corporate institutions like Royal Bafokeng Holdings, the interpellation of new political subjects (the subject or citizen or shareholder), and the formation of new individual and collective subjectivities (the Bafokeng "ethnic corporation"), presage important debates among elites and constituencies about the meaning of community, sovereignty, and progress, which are not easily resolved, and in fact unfold variously on contemporary African terrains. ${ }^{9}$

\begin{abstract}
Sovereignty and governance in contemporary Africa are hotly contested issues with important - even dire - consequences for all those interested in the continent's markets, resources, people, and welfare. This article focuses not on questions of how authority is assigned or removed but on how it is shaped, worn, and performed for diverse audiences, particularly in the arena of "traditional governance." Here, the Bafokeng "ethnic corporation” meets Africa's last absolute monarchy, the Swazi Kingdom, in a juxtaposition of styles, symbols, and strategies that illuminates the difference between an aesthetic of defiant African alterity and an Afromodern capitalist cosmopolitanism.
\end{abstract}

\title{
NOTES
}

Acknowledgments. We would like to thank the many people in Bafokeng and Swaziland who hosted us, welcomed us, and made it possible for us to observe and participate in the events we describe here. Special thanks go to Kgosi Leruo Molotlegi, whose intellectual curiosity, commitment to honest inquiry, and generosity made broad and spontaneous engagement with the Bafokeng community such a pleasure. We would also like to thank several colleagues who read and commented on earlier iterations of this article, including Bilal Butt, Walker Depuy, John Comaroff, Nadine Naber, Julia Paley, Damani Partridge, Nick Reo, Elizabeth Roberts, and Miriam Ticktin. Carly Edwards offered expert research assistance and formatting; Keith Brown offered helpful insights in the final stages of editing. We are also grateful for input from an unusually wide array of reviewers for this journal due to the way our manuscript's emphasis shifted, over the course of an editorial transition at Cultural Anthropology. Any errors of fact or interpretation belong solely to the authors.

1. This follows Cattelino's analysis of the Florida Seminole Nation, in which she argues that cultural sovereignty has to do with the ability of a group to retain or redefine symbols and practices from past in experiments with new social and economic forms (Cattelino 2008).

2. We chose the Swazi case for the useful and rich contrasts it presents. Our observations of the Bafokeng King's interactions with the Asantehene of Ghana, the "Maori King” (Kiingi Tuheitia of the Turangawaewae Marae) of New Zealand, and tribal leaders from the Florida Seminole Nation also reliably bear out our analysis but were omitted due to space constraints. 
3. As in other African monarchies, the Swazi queen mother is the custodian of royal register and pronounces on questions of eligibility regarding succession disputes. When a Swazi king dies, it is through the selection of a new queen mother that succession occurs.

4. For more information about this use of a company, quite different from the way the Bafokeng are creating corporate structures, see the following sources: the official web page at http://ww2.tibiyo.com (last accessed January 28, 2013; articles in the Mail and Guardian such as this (2011b) one, by a staff reporter http://mg.co.za/article/2011-08-05it-is-not-a-bailout-but-handout-from-sugar-daddy (last accessed January 28, 2013).

5. From 2007-13, Cook served as the director of research for the Royal Bafokeng Administration, a shift that offered much greater access to the inner logics (and contradictions) of the institution, as well as a position of influence from which to study and shape specific policy conversations. Although there are legal and contractual constraints on what a senior official in the administration may say about its work, Cook experienced the constraints deriving from this difference in positionality to be mostly those of time, rather than opportunity, for critical reflection.

6. "King Mswati has had to contend with repeated controversy surrounding his first wife ... [who] defied a royal tradition that the queen could not have a public job" reports the BBC. "Royal sources say that she is trying to ensure that her first-born son, Prince Lindani, succeeds to the throne" (BBC 2001).

7. We thank Jane Guyer for this insight about these different, but now interrelated concepts of the "corporate" in our study context.

8. In terms of actual redistribution of mining wealth, the Bafokeng Supreme Council approved a budget of R922.5 million (USD 118 million) for 2012. These funds were drawn primarily from dividends from Royal Bafokeng Holdings's investments, and included funds for public utilities, education, sports, health, public safety, and food security (Molotlegi 2012).

9. Although it falls outside the scope of this article, the widespread and deadly labor disputes that were engulfing the platinum belt, including the Bafokeng region, at the time of writing, can thus be understood as an outcome of the experiments in "brutally profitable methods of labor discipline ... and in untried practices of governance and extraction" that constituted some of the "innovations" of the global South during the colonial period (Jean Comaroff and John Comaroff 2012b:5).

\section{REFERENCES CITED}

$\mathrm{BBC}$

2001 Troubled King Mswati. BBC News, December 4. http://news.bbc.co.uk/ 2/hi/africa/1692217.stm.

2002a Swazi Court Defies King. BBC News, November 15. http://news.bbc.co.uk/ 2/hi/africa/2481687.stm.

2002b Swazi Prosecutor Sticks to His Guns. BBC News, November 1. http: / / news.bbc. co.uk/2/hi/africa/2385849.stm.

2004 Swazi King Chooses Another Wife. BBC News, September 6. http: //news.bbc. co.uk/2/hi/africa/3630800.stm.

2005 Swazi King Drops Sex-Ban Tassels. BBC New, August 23. http://news.bbc. co.uk/2/hi/africa/4165432.stm.

Breutz, P. L.

1953 The Tribes of Rustenburg and Pilanesberg Districts. Pretoria: The Government Printer.

Cattelino, Jessica

2008 High Stakes: Florida Seminole Gaming and Sovereignty. Durham: Duke University Press.

Coertze, R. D.

1988 Bafokeng Family Law and Law of Succession. Pretoria: SABRA. 
Comaroff, John L., and Jean Comaroff

1997 Of Revelation and Revolution: The Dialectics of Modernity on a South African Frontier, Vol. 2. Chicago: University of Chicago Press.

2009 Ethnicity, Inc. Chicago: Chicago University Press.

Comaroff, Jean, and John Comaroff

1991 Of Revelation and Revolution: Christianity, Colonialism, and Consciousness in South Africa, Vol. 1. Chicago: University of Chicago Press.

2012a Theory from the South: Or, How Euro-America Is Evolving toward Africa (The Radical Imagination). Boulder, CO: Paradigm.

2012b Theory from the South: A Rejoinder. Cultural Anthropology (http://www. Cook, Susan E. culanth.org), accessed March 8, 2012.

2005 Chiefs, Kings, Corporatization and Democracy: A South African Case Study. Brown Journal of World Affairs 12.1:125-137.

2011 The Business of Being Bafokeng: Corporatization in a Tribal Authority in South Africa. Current Anthropology 52 (Suppl. 3): S151-S159.

Ferguson, James G.

1999 Expectations of Modernity: Myths and Meanings of Urban Life on the Zambian Copperbelt. Berkeley: University of California Press.

Gulbrandsen, Ornulf

1995 The King Is King by the Grace of the People: The Exercise and Control of Power in Subject-Ruler Relations. Comparative Studies in Society and History 37(3):415-444.

Hansen, Karen T.

2004 The World in Dress: Anthropological Perspectives on Clothing, Fashion, and Culture. Annual Review of Anthropology 33:369392.

Hardin, Rebecca, and Kamari Maxine Clarke, eds.

2012 Transforming Ethnographic Knowledge. Madison: University of Wisconsin Press. Hendrickson, Hildi

1996 Clothing and Difference: Embodied Identities in Colonial and Post-Colonial Africa. Duke: Duke University Press.

Hobsbawm, E., and T. Ranger

1992 The Invention of Tradition. Cambridge: Cambridge University Press. Integrated Regional Information Networks (IRIN)

2009 Swaziland: A Culture that Encourages HIV/AIDS. http://www.unhcr.org/ refworld/docid/49e6ef2dc.html, accessed October 21, 2009.

Kuper, Hilda

1961 [1947] An African Aristocracy: Rank among the Swazi. London: Oxford University Press.

1963 The Swazi: A South African Kingdom. New York: Holt, Rinehart and Winston. Landau, Paul S.

1995 The Realm of the Word: Language, Gender, and Christianity in a Southern African Kingdom. Portsmouth, NH: Heinemann.

Legassick, Martin

1969 The Sotho-Tswana Peoples before 1800. In African Societies in Southern Africa. L. Thompson, ed. Pp. 86-125. New York: Praeger.

MacGregor, Karen

2002 The King and the Virgin. Newsweek, November 1.

Mail and Guardian

2011a Swaziland's Economy Near Collapse, Says IMF. November 16. http://mg.co.za/ article/2011--11--16-swazilands-economy-near-collapse-says-imf/.

2011 b Swaziland “A Handout from a Sugar Daddy.” August 5. http://mg.co.za/article/ 2011--08--05-it-is-not-a-bailout-but-handout-from-sugar-daddy 
Mamdani, Mahmood

1996 Citizen and Subject: Contemporary Africa and the Legacy of Late Colonialism. Princeton, NJ: Princeton University Press.

Manson, Andrew

In press Mining and "Traditional Communities” in South Africa's North-West Province, c. 1996-2012: Contestations over Land, Leadership and Assets. Journal of Southern African Studies.

Manson, Andrew, and Bernard Mbenga

2003 "The Richest Tribe in Africa": Platinum-Mining and the Bafokeng in South Africa's North West Province, 1965-1999. Journal of Southern African Studies 29(1):2547.

Mbenga, Bernard, and Andrew Manson

2010 "People of the Dew": A History of the Bafokeng of Phokeng-Rustenburg Region, South Africa, from Early Times to 2000. Johannesburg: Jacana Media.

Molotlegi, Leruo T.

2012 RBN Review Speech. Phokeng: Royal Bafokeng Administration.

Ntsebeza, Lungisile

2005 Democracy Compromised: Chiefs and the Politics of Land in South Africa. Leiden: Brill.

Oomen, Barbara

2005 Chiefs in South Africa: Law, Power and Culture in the Post-Apartheid Era. Oxford: James Currey.

Platinum Weekly

2012 “A Lawless Culture.” http://www.platinumweekly.co.za/article954.html, accessed March 8, 2012.

Rathbone, Richard

2000 Nkrumah and the Chiefs: The Politics of Chieftaincy in Ghana, 1951-1960. Athens: Ohio University Press.

Ribot, Jesse

1996 Participation without Representation: Chiefs, Councils and Forestry Laws in the West African Sahel. Cultural Survival Quarterly 20:3 (Fall).

Royal Bafokeng Administration

2011 The Population and Use of Land Audit (PULA 1 and 2). Phokeng.

Schapera, Isaac

1943 Tribal Legislation among the Tswana of the Bechuanaland Protectorate: A Study in the Mechanism of Cultural Change. London: Lund Humphries.

1952 The Ethnic Composition of Tswana Tribes. London: The London School of Economics and Political Science.

Schapera, Isaac, and John L. Comaroff

1991 The Tswana. Rev. edition. London: Kegan Paul International.

Skalnik, Peter

2004 Chiefdom: A Universal Political Formation? Focaal-European Journal of Anthropology 43(2004):76-98.

South African

2003 Bafokeng King Takes the Throne. August 20. http://www.southafrican. co.uk/newsread.asp?newsid $=17$.

Thomson Reuters

2012 Africa's "Richest Tribe" Offers Platinum Model. October 18.

UNAIDS

2009 Swaziland Fact Sheet. http://www.unaids.org/en/regionscountries/countries/ swaziland/, accessed April, 29, 2012.

Welker, Marina, Damani Partridge, and Rebecca Hardin

2011 Corporate Lives: New Perspectives on the Social Life of the Corporate Form. Current Anthropology 52 (S3):S3-S16. 
Wastell, Sari

2006 The Legal Thing in Swaziland: Res Judicata and Divine Kingship. In Thinking Through Things. Amiria Henare, Martin Holbraad, and Sari Wastell, eds. Pp. 68-92. London: University College London Press.

2007 Being Swazi, Being Human: Custom, Constitutionalism, and Human Rights in an African Polity. In The Practice of Human Rights: Tracking Law between the Global and the Local. Mark Goodale and Sally Engle Merry, eds. Pp. 320-341. Cambridge: Cambridge University Press.

Wylie, Diana

1990 A Little God: The Twilight of Patriarchy in a Southern African Chiefdom. Hanover, CT: Wesleyan University Press.

\section{Supporting Information}

Additional Supporting Information may be found in the online version of this article at the publisher's website:

Figure S1. King Molotlegi, promoting a 2013 partnership between the U.S. NBA and the Royal Bafokeng.

Figure S2. Image of King Mswati and his daughter at the 2013 umhlanga ritual.

Figure S3. The proximity of elite guests to the Tswana chief, while his subjects stand outside, looking in.

Figure S4. Molotlegi enters the enthronement in a traditional donkey cart to show humility, but cloaked in a traditional leopard skin, over his tailored suit. 